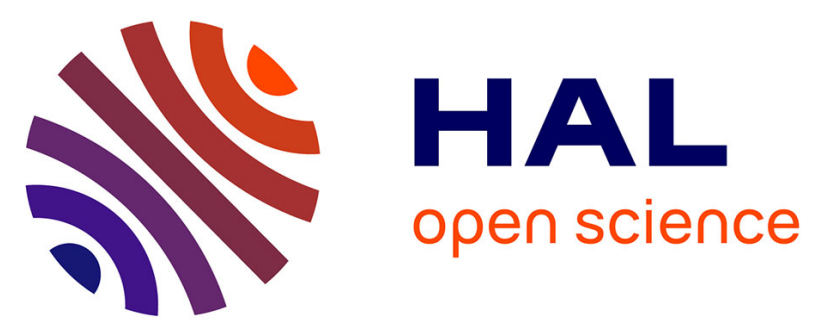

\title{
Genetic parameters and comparison between native and local landraces of Eucalyptus globulus Labill. ssp. globulus growing in the central highlands of Colombia
} Martha Salas, Víctor Nieto, Liliana Perafán, Alejandro Sánchez, Nuno M. G. Borralho

\section{To cite this version:}

Martha Salas, Víctor Nieto, Liliana Perafán, Alejandro Sánchez, Nuno M. G. Borralho. Genetic parameters and comparison between native and local landraces of Eucalyptus globulus Labill. ssp. globulus growing in the central highlands of Colombia. Annals of Forest Science, 2014, pp.405-414. 10.1007/s13595-013-0342-4 . hal-01101532

\section{HAL Id: hal-01101532 \\ https://hal.science/hal-01101532}

Submitted on 8 Jan 2015

HAL is a multi-disciplinary open access archive for the deposit and dissemination of scientific research documents, whether they are published or not. The documents may come from teaching and research institutions in France or abroad, or from public or private research centers.
L'archive ouverte pluridisciplinaire HAL, est destinée au dépôt et à la diffusion de documents scientifiques de niveau recherche, publiés ou non, émanant des établissements d'enseignement et de recherche français ou étrangers, des laboratoires publics ou privés. 


\title{
Genetic parameters and comparison between native and local landraces of Eucalyptus globulus Labill. ssp. globulus growing in the central highlands of Colombia
}

\author{
Martha Salas • Víctor Nieto • Liliana Perafán • \\ Alejandro Sánchez • Nuno M. G. Borralho
}

Received: 21 March 2013 /Accepted: 16 October 2013 /Published online: 15 November 2013

(C) INRA and Springer-Verlag France 2013

\begin{abstract}
- Aims The objective of this study was to compare the merit of the Colombian landrace relative to the various Australian native races of Eucalyptus globulus Labill. ssp. globulus and study the genetic control of key traits such as growth, wood density, and leaf phase change in the unique conditions of the Colombian highlands.

- Methods The genetic study was based on open-pollinated families from native Australian and Colombian landrace origin, tested across four trials spanning two generations of breeding. A multisite mixed linear model with genetic groups was fitted to the data to estimate race merit and the variance and covariances between traits, ages, and sites.

- Results Race effects for growth were small and only significant at the older site. In contrast, races differ significantly for height to phase change and density. The Colombian landrace and South and NE Tasmania races changed leaf type
\end{abstract}

\section{Handling Editor: Jean-Michel Leban}

Contribution of the co-authors Salas, M., Nieto, V: designed the research.

Salas, M., Perafán, L., López, A., and Nieto, V.: performed the research. Borralho, N., Salas, M., and Perafán, M.: analyzed the data.

Borralho, N., Salas, M., and Nieto, V.: wrote the paper.

M. Salas $\cdot$ L. Perafán

Smurfit Kappa Cartón de Colombia S. A.,

Calle 15 No. 18-109 Puerto Isaacs, Yumbo, Colombia

M. Salas

e-mail: martha.salas@smurfitkappa.com.co

L. Perafán

e-mail: liliana.perafan@smurfitkappa.com.co

V. Nieto

Corporación Nacional de Investigación y Fomento Forestal (CONIF), Calle 71 No..12-67, Piso 4, Bogotá D.C., Colombia

e-mail: victornieto@conif.org.co at a higher tree height. King Island and Recherche Bay had low density values, whereas the Colombian landrace had the highest. Heritability was moderate for growth traits (between 0.09 and 0.40 ), high for height to phase change (between 0.42 and 0.69 ), and moderate for wood density (0.28). The genetic correlation between growth and height to phase change was in general positive, but variable across sites. There was no correlation between growth and density. Despite large differences in growth between trials, pairwise genetic correlations suggest that genotype-by-site interaction is negligible. However, there was a poor correspondence between first-generation (ex-native stands) and second-generation families (ex-multi-provenance progeny trial). This suggests that breeding value estimates based on native open-pollinated material are unreliable.

- Conclusion Results confirm negligible race differences for growth, but not for wood density. Future breeding efforts

\author{
A. Sánchez \\ Universidad Distrital "Francisco José de Caldas", \\ Carrera 5 Este No. 15-82, Bogotá D.C., Colombia \\ e-mail: alejoforestal@hotmail.com \\ N. M. G. Borralho \\ Urb S Francisco 18, 2070-220 Cartaxo, Portugal \\ N. M. G. Borralho $(\bowtie)$ \\ Centro de Estudos Florestais, Instituto Superior de Agronomia, \\ Universidade Técnica de Lisboa, \\ Tapada da Ajuda, 1349-017 Lisbon, Portugal \\ e-mail: nunoborralho@sapo.pt
}


should include the various genetic backgrounds including the Colombian landrace which constitutes a very important source, especially because of its high density. Despite a low Genotype by Environment interaction, the poor genetic correspondence between the first- and second-generation trials indicates that selections for growth should be based on information coming mainly from the advanced-generation trials.

Keywords Eucalyptus $\cdot$ Race effects $\cdot$ Heritability $\cdot$ Genetic correlations · GE interaction · Growth · Wood density · Heteroblasty

\section{Introduction}

Eucalyptus globulus Labill. ssp. globulus is a temperate species native in Australia (Tasmania, Bass Straight Islands, and Southern Victoria), where it grows at low altitudes along the coastline, at latitudes between 39 and $43^{\circ} \mathrm{S}$. Successful plantations have been established at similar latitudes and climate in both the Northern (e.g., Portugal and Spain) and Southern Hemispheres (Western Australia, Chile, or Uruguay). However, the species finds also exceptional growing conditions in Colombia's central highlands, at latitude 1.5 to $6^{\circ} \mathrm{N}$ and altitudinal ranges between 1,900 and $3,000 \mathrm{~m}$ (Venegas 1989). These regions have a temperate highland tropical climate, with distinct but mild dry "winters" (of type $C w c$, according to the Köppen-Geiger classification; Kottek et al. 2006). It has also a peculiar rainfall distribution around the year, with two drier periods in January and June/ July and two wetter periods in April/May and October/ November. This is the first time a thorough investigation of the genetics of E. globulus is carried out under such ecological conditions.

E. globulus constitutes an important forestry resource in Colombia, supplying Smurfit Kappa Cartón de Colombia's paper mill (the largest in the country) with a significant proportion of its total short-fiber pulpwood requirements. The species is also popular for mine levers, light posts, greenhouse structures, and stacks (Salas and Salazar 2007). Typical harvesting age is around 10 years for pulpwood, but may be considerably longer depending on the end uses. The introduction of E. globulus ssp. globulus in Colombia is thought to have taken place in the late nineteenth century, although the original sources remain unknown. To broaden the genetic basis and support a genetic improvement effort for the species in Colombia, Inderena, the country's Natural Resources National Institute at the time, established in 1982 a large progeny/provenance trial, near Bogotá. The collection included several families collected from native stands in Tasmania and the Bass Strait Islands of King and Flinders, by the then Forestry Commission (Australia). This initial trial was subsequently thinned and converted into a seed orchard
(Venegas 1989). Between 2006 and 2007, seed was collected from 129 trees in this trial, each one belonging to a different family, hence preserving nearly all of the initial family and provenance structure. These second-generation families were subsequently established, in 2008, at three locations also in Colombia's central plateau.

The objectives of this study were to (1) compare the merit of the Colombian landrace relative to the various Australian native races and (2) study the genetic control and stability across sites of key traits for this species in the unique ecological conditions of the Colombian highlands. The variables studied included growth over time, wood density, and height at which leaf phase changed from juvenile to adult type. Such information is important to optimize the selection strategies to be implemented in the third-generation breeding program of this species. The genetics of leaf type changes is relevant in the context of its relationship with tolerance or avoidance mechanisms against pests and diseases (as discussed in Steinbauer 2002; Brennan and Weinbaum 2001; Milgate et al. 2005), some of them of economic importance to E. globulus worldwide.

\section{Materials and methods}

\subsection{Original (first-generation) collection}

The original seed collection included in this study consisted of a total of 158 open-pollinated families, 106 of which are of Australian origin (ex-native stands) and 52 from the Colombian landrace. This collection was established at a single site in 1983, at the La Florida site. The Australia families were collected at several locations in Tasmania, King Island, and Flinders Island and belong to what has been referred to as the "Orme Collection" since it was originally assembled by Keith Orme, then at the Forestry Commission in Tasmania (Australia). This collection represents mainly $E$. globulus ssp. globulus core populations and has been distributed to several organizations in many countries (e.g., Orme 1978; Volker and Orme 1988). Details of the locations and racial classification from where these seedlots have been sampled are given in Table 1. The racial classification used followed Dutkowski and Potts (1999). In the collection, Northeast Tasmania, southeastern Tasmania, and southern Tasmania are well represented, with over 25 families each. The Bass Strait Islands races (King Island and Flinders Islands) are much worse represented, with only five families each; Western Tasmania, a small possibly relic population, and Recherche Bay have intermediate representation, with ten families each. The families of Colombian landrace were collected from plus trees selected in commercial stands and woodlands in the Boyacá, Cundinamarca, and Nariño departments. 
Table 1 Families included in the original (first-generation) trial at the La Florida site and the subsequent three secondgeneration progeny trials according to their race, sub-race, and location. Racial classification follows Dutkowski and Potts (1999)

\begin{tabular}{|c|c|c|c|c|}
\hline Race & Sub-race & Location & $\begin{array}{l}\text { Original } \\
\text { collection }\end{array}$ & $\begin{array}{l}\text { Second-generation } \\
\text { trials }\end{array}$ \\
\hline Furneaux Group & Flinders Island & South Flinders Is & 5 & 3 \\
\hline King Island & King Island & King Island & 5 & 5 \\
\hline \multirow[t]{4}{*}{ NE Tasmania } & \multirow[t]{2}{*}{ Inland NE Tasmania } & Jericho & 5 & 2 \\
\hline & & Pepper Hill & 5 & 3 \\
\hline & NE Tasmania & Seymour & 10 & 7 \\
\hline & St. Helens & St. Helens & 6 & 6 \\
\hline \multirow[t]{3}{*}{ SE Tasmania } & \multirow[t]{3}{*}{ SE Tasmania } & Chanel & 10 & 10 \\
\hline & & Rheban & 10 & 9 \\
\hline & & Uxbridge & 5 & 3 \\
\hline \multirow[t]{3}{*}{ Southern Tasmania } & \multirow[t]{3}{*}{ Southern Tasmania } & Bruny Island & 10 & 7 \\
\hline & & Geeveston & 10 & 7 \\
\hline & & Denison & 5 & 2 \\
\hline Recherche Bay & Recherche Bay & Leprena & 10 & 7 \\
\hline \multirow[t]{2}{*}{ Western Tasmania } & \multirow[t]{2}{*}{ Western Tasmania } & Henty River & 5 & 5 \\
\hline & & Macquary Harbour & 5 & 4 \\
\hline \multirow[t]{3}{*}{ Colombian landrace } & & Boyacá & 11 & 11 \\
\hline & & Cundinamarca & 35 & 32 \\
\hline & & Nariño & 6 & 6 \\
\hline
\end{tabular}

\subsection{Second-generation population}

Between 2005 and 2007, open-pollinated seeds were taken from a single offspring tree from each of 129 of the original 158 families present at the La Florida trial. These families included 80 of Australian origin and 49 from the Colombian landrace. Since seed was collected from only one tree per family, the 129 second-generation families remained unrelated from their mother's side, but shared a common pollen source. They are expected to have a half-nephew/half-uncle relationship (i.e., an intra-class relationship of 1/8), with the corresponding first-generation families from where the mother tree was sampled. Since the 129 mother trees from where seed was sampled were known, there are also some parentoffspring relationships between the two trial series.

\subsection{Field trials}

The single trial with the original (first-generation) collection and the more recent (second-generation) progeny trials are all located in the Cundiboyacense Plateu, in Central Colombia (Table 2). The experimental design at the La Florida trial consisted of nine randomized complete blocks, with each family represented initially by a five-tree plot in each replicate. The five trees were displayed in a shape of a cross, with the central tree surrounded by the other four at a closer spacing of $1 \mathrm{~m}$ apart, and central trees spaced $5 \mathrm{~m}$ apart from the next central tree of the neighbor plot. At age 6 , the trial was thinned, leaving in each plot the best tree out of the five, hence converting the experiment to a single-tree plot design, albeit with a somewhat irregular spacing. The three secondgeneration trials (denoted Firavitoba, Tuta, and Santa Rosa) were established as 15 randomized complete replicates with a single tree per family per replicate and the trees planted at a $3 \times$ 3-m spacing. All sites were cultivated prior to planting and fertilized at planting. Subsequent maintenance included manual and chemical weed controls as required.

\subsection{Measurements}

The variables measured at the La Florida trial were diameter at $1.3 \mathrm{~m}$ (diameter at breast height, dbh) at ages $3,11,17$, and 23 and wood density at age 11 , based on a single wood drill core

Table 2 Location and characteristics of the four progeny trials analyzed in this study

\begin{tabular}{lllll}
\hline & La Florida & $\begin{array}{l}\text { Santa } \\
\text { Rosa }\end{array}$ & Firavitoba & Tuta \\
\hline Department & Cundinamarca & Boyacá & Boyacá & Boyacá \\
Latitude & $4^{\circ} 44^{\prime}$ & $5^{\circ} 51^{\prime} \mathrm{N}$ & $5^{\circ} 43^{\prime} \mathrm{N}$ & $5^{\circ} 39^{\prime} \mathrm{N}$ \\
Longitude & $74^{\circ} 09^{\prime} \mathrm{W}$ & $72^{\circ} 59^{\prime} \mathrm{W}$ & $73^{\circ} 00 \mathrm{~W}$ & $7^{\circ} 09^{\prime} \mathrm{W}$ \\
Elevation (m a.s.1.) & 2,550 & 2,724 & 2,914 & 2,800 \\
Precipitation (mm) & 785 & 973 & 663 & 827 \\
Area (ha) & 3.4 & 2.5 & 2.5 & 2.5 \\
Setup date & January 1983 & May 2008 & May 2008 & May 2008 \\
No. of families & 158 & 129 & 127 & 128 \\
\hline
\end{tabular}


taken also at $1.3 \mathrm{~m}$ and using a standard Pressler borer. The density, based on cores, was measured using the standard water displacement method to calculate green volume over its corresponding oven dry weight. Although thinning was carried out at age 6 , the 3 -year-old measurements refer only to the trees which remain after the thinning.

In the three second-generation trials, measurements included tree height and dbh at ages 1, 2, 3, and 4 years. From these measurements, volume under over bark per tree was estimated using the following equation:

$V=\left(0.0003 D^{1.82210}\right)\left(H^{1.17322}\right)$

where $V$ is total volume over bark per tree (in cubic meters), $D$ is the diameter at breast height (in centimeters), and $H$ is total height (in meters). The volume equation was developed for young E. globulus growing in Chile, by Gilabert and Paci (2010), and was used here since no specific volume equation for E. globulus is available in Colombia.

At age 2.6 years, height where transition from juvenile to adult leaf form occurred was first recorded (denoted height to phase change or HTPC thereof). This was taken as the height where leaves started to be petiolated and having the lanceolated shape, typical of the E. globulus adult leaves. In trees where phase change had not occurred by age 2.6 years, a new measurement was taken at age 3. By then, only 0.6, 2.7, and $3.6 \%$ of the trees in Santa Rosa, Firavitoba, and Tuta, respectively, had its entire canopy with juvenile foliage. In this case, its height to phase change was set to the total height at age 3 .

\subsection{Statistical analysis}

To provide with an appropriate test of significance for race effects, a simple model was first fitted to the data, of the type (model 1)

$y=\mathbf{X} \boldsymbol{r}+\mathbf{Z} \boldsymbol{f}+e_{\mathrm{w}}$

(Model1)

where $\boldsymbol{r}$ is the vector of fixed effects due to replicates within site and groups (or races); $\boldsymbol{f}$ the vector of family effects (within race), fitted as random; and $e_{\mathrm{w}}$ the within-family residual. The matrices $\mathbf{X}$ and $\mathbf{Z}$ are design matrices, relating the vector of $y$ measurements to their corresponding effects.

Test of significance for race effects was based on an $F$ statistic, derived from Wald test's incremental form (Gilmour et al. 1998), with the numerator degrees of freedom ( $d f$ ) equal to the number of races and the denominator $d f$ approximated as the residual degrees of freedom.

Variance and covariance between traits within a site were estimated using a family model similar to model 1 , but now considering family and error variance-covariance matrices as $\mathbf{F} \otimes \mathbf{I}_{t}$, where $\mathbf{F}$ is the family variance-covariance matrix between traits (assumed unstructured and of size $t \times t$ ), $\mathbf{I}_{t}$ is an identity matrix of size $t$ (the number of traits), and $\otimes$ is the Kronecker product of matrices.

A multisite analysis was carried out between the three second-generation trials. This was also based on a family model of the type

$y=\mathbf{X} \boldsymbol{r}+\mathbf{Z} \boldsymbol{f}+e_{\mathrm{w}}$

(Model2)

where $\boldsymbol{r}$ includes now the fixed effects due to sites, replicates within site, and groups (or races) within site; $f$ the family effects within race and site, fitted as random; and $e_{\mathrm{w}}$ the within-family residual. The matrices $\mathbf{X}$ and $\mathbf{Z}$ are design matrices relating observations to corresponding effects. Family effects were defined as $\mathbf{S} \otimes \mathbf{I}_{s}$, where $\mathbf{S}$ is the $s \times s$ family variance-covariance matrix across sites (assumed unstructured) and $\mathbf{I}_{s}$ is an identity matrix of size $s$ (the number of sites). This implies a separate family variance at each site, and since the same families are tested across sites, the corresponding pairwise family covariances are also estimable. Finally, the error term was fitted to each site as

$\mathbf{R}=\oplus_{j=1}^{s} R_{j}=\oplus_{j=1}^{s} \boldsymbol{I}_{j} \sigma_{\text {ewj }}^{2}$

Therefore, in model 2 , each $j$ th site had its own independent within-family residual variance $\left(\sigma_{e w j}^{2}\right)$, with $\mathbf{R}$ having a diagonal structure.

Finally, for the analysis which pooled the first- and secondgeneration trials, an additive individual tree model with genetic groups was fitted (Westell et al. 1988; Da and Grossman 1991). This can be expressed as

$y=\mathbf{X} \boldsymbol{r}+\mathbf{Z} \boldsymbol{a}+\mathbf{Z Q} \boldsymbol{g}+e$

(Model3)

where $y$ is the vector of observations, $r$ is the vector of fixed effects due to sites and replicates within site, $\boldsymbol{a}$ the vector of additive genetic effects, and $\boldsymbol{g}$ the race effects within site, both fitted as random; $e$ is the residual. The matrices $\mathbf{X}$ and $\mathbf{Z}$ are design matrices relating observations to corresponding effects; the elements in $\mathbf{Q}$ are the fractions relating each tree to the contributions of the corresponding races in its genetic value. The variance structure for the additive genetic effects are now given as $\boldsymbol{G}=\mathbf{A} \otimes \mathbf{G}_{s}$, where $\mathbf{G}_{\mathrm{s}}$ is the variance-covariance matrix for the additive genetic effects across sites and $\mathbf{A}$ is the numerator relationship matrix amongst all individual trees. Although no individual tree was tested across sites, many trees are related, either as half-sibs (among second-generation trials) or as uncle-nephew and parent-offspring (between the firstgeneration trial and the other three second-generation trials). As previously, model 3 assumed a heterogeneous error term as

$\mathbf{R}=\oplus_{j=1}^{s} R_{j}=\oplus_{j=1}^{s} \boldsymbol{I}_{j} \sigma_{e j}^{2}$

The genetic grouping is relevant when pooling first- and second-generation trials because there are different sources of pollen involved in the first- and second-generation open- 
pollinated families. In the first-generation trial, male and female backgrounds are the same (since seed was collected in native stands). However, in the second-generation collection, this was not the case. Although female parents belonged to a known ancestral group or race, the pollen would be a mix of several races present at the La Florida trial, assuming the pollination had a reasonable mixture of genetic backgrounds. Therefore, the genetic groups need to consider not only the various Australian races and Colombian landrace but also a mix-pollen group to account for the mixed paternal background of the second-generation families.

The various solutions to the mixed model equations and corresponding variance-covariance estimates were solved based on a REML/BLUP method using the AsReml software (Gilmour et al. 1998). Heritability estimates assumed an intraclass correlation among family sibs of $r=1 / 3$, hence considered a substantial but unknown amount of selfing is present (see Squillace 1974 for a derivation of $r$ based on selfing rates and sib relatedness). Hence, for model 2, heritability was calculated as

$h^{2}=\frac{3.33 \widehat{\sigma}_{\mathrm{f}}^{2}}{\widehat{\sigma}_{\mathrm{f}}^{2}+\widehat{\sigma}_{e \mathrm{~W}}^{2}}$

where $\widehat{\sigma}_{f}^{2}$ and $\widehat{\sigma}_{e w}^{2}$ are the estimates of family and withinfamily residual variances.

For model 3, a direct estimate of $\widehat{\sigma}_{a}^{2}$ was obtained, but it assumes $r=1 / 4$. A correction for $r=1 / 3$ was done as

$h^{2}=\frac{k \widehat{\sigma}_{\mathrm{a}}^{2}}{\widehat{\sigma}_{\mathrm{a}}^{2}+\widehat{\sigma}_{\mathrm{e}}^{2}}$

where $\widehat{\sigma}_{a}^{2}$ and $\widehat{\sigma}_{e}^{2}$ are the original estimates of additive genetic and error variance and $k=3.3 / 4$. Genetic correlations were estimates for model 1 (multi-trait) and model 2 (multisite) as

$r_{\mathrm{G}}=\frac{\widehat{\sigma}_{\mathrm{f} 1, \mathrm{f} 2}}{\widehat{\sigma}_{\mathrm{f} 1} \widehat{\sigma}_{\mathrm{f} 2}}$

And for model 3 (multisite) as

$r_{\mathrm{G}}=\frac{\widehat{\sigma}_{\mathrm{a} 1, \mathrm{a} 2}}{\widehat{\sigma}_{\mathrm{a} 1} \widehat{\sigma}_{\mathrm{a} 2}}$

where $\widehat{\sigma}_{f 1, f 2}$ and $\widehat{\sigma}_{a 1, a 2}$ are the family and additive genetic covariances, respectively, either between traits or for the same trait between trials.

Standard errors for heritabilities and correlations were approximated by the so-called delta method (viz., Lynch and Walsh 1998), as calculated using AsReml. Whenever relevant, significance of random effects was calculated based on a likelihood ratio test (McCullagh and Nelder 1989) with $0.5 d f$.

\section{Results}

\subsection{Site means and race effects}

Mean productivity and height to phase change varied significantly between sites. Of the three second-generation trials, Santa Rosa had the fastest growth at age 4, with an average height, diameter, and estimated tree volume of $11.2 \mathrm{~m}, 9.7 \mathrm{~cm}$, and $0.035 \mathrm{~m}^{3}$, respectively, which correspond to a mean annual increment at age 3 of approx. $12 \mathrm{~m}^{3} \mathrm{ha}^{-1}$ year $^{-1}$. Mean volumes at Firavitoba and Tuta were only 0.010 and $0.004 \mathrm{~m}^{3}$, respectively. The initial growth of the first-generation La Florida trial was slower compared with the second-generation trials, at least until age 3 . However, by age 7 , its diameter seems to fall within the expected growth trajectory of the fastest growing Santa Rosa trial. After age 11, diameter increments at La Florida had clearly slowed down, but by then, the mean diameter was an impressive $40 \mathrm{~cm}$.

Race effects for growth were significant only at the La Florida site, and only at ages 7 and 11 (Table 3). At this site, King Island was initially the best race, but by age 23 , it has been outperformed by Flinders Islands and SE and NE Tasmania races. The Colombian landrace had an intermediate performance, relative to the native Australian races, at least until age 11 , but by age 23 , the Colombian landrace was one of the worse in the trial. In the three second-generation trials, race differences for growth (height, diameter, and volume) were always small and never statistically significant (Table 4). At Santa Rosa and Tuta, where race differences were nevertheless more pronounced, the best races included Western Tasmania and Flinders Islands, whereas the Colombian landrace was ranked below average. Wood density was only measured at age 11, and only at the La Florida site. Here, differences between races were highly significant (Table 3), with King Island and Recherche Bay having low densities (540 and $556 \mathrm{~kg} / \mathrm{m}^{3}$, respectively), whereas the Colombian landrace, Furneaux, and SE Tasmania had the highest (around $587 \mathrm{~kg} / \mathrm{m}^{3}$ ).

Differences in HTPC between trials were small but significant, being 4.2, 4.6, and $4.0 \mathrm{~m}$ at Firavitoba, Santa Rosa, and Tuta, respectively. The HTPC was related to the trial's total height, with faster growing sites changing leaf type at a higher height. The HTPCs differ significantly between races at all sites $(P<0.001$; Table 4$)$, with race effects remaining stable across sites. Western Tasmania, Furneaux Group, and King Island changed to adult foliage at a much lower tree height than the NE and Southern Tasmanian races or the Colombian landrace, the differences being often greater than $1 \mathrm{~m}$.

\subsection{Genetic parameters}

The estimated heritability for growth ranged between 0.10 and 0.40 (Table 5). The diameters were measured at the La Florida 
Table 3 Race effects at the La Florida trial for dbh $(D$, in centimeters) at ages $3,7,11$, and 23 years and density (DEN, in kilograms per cubic meter) at age 11. A Wald $F$ test and the expected probability of a significant difference are included

\begin{tabular}{llllll}
\hline Race & D3 & D7 & D11 & D23 & DEN11 \\
\hline Southern Tasmania & 6.8 & 26.2 & 32.6 & 40.2 & 584.0 \\
NE Tasmania & 6.9 & 25.9 & 31.0 & 40.9 & 581.4 \\
SE Tasmania & 7.4 & 27.8 & 34.7 & 41.1 & 587.1 \\
Recherche Bay & 6.8 & 26.7 & 34.0 & 36.4 & 555.6 \\
Western Tasmania & 6.7 & 24.6 & 30.6 & 36.2 & 571.7 \\
Furneaux & 6.8 & 25.6 & 31.1 & 43.6 & 586.6 \\
King Island & 7.5 & 31.8 & 38.6 & 39.4 & 540.3 \\
Colombia LR & 6.9 & 27.7 & 34.0 & 36.8 & 590.2 \\
$F$-inc (prob) & $2.66(2.6 \%)$ & $4.73(<0.1 \%)$ & $3.78(<0.1 \%)$ & $2.58(3.2 \%)$ & $6.74(<0.1 \%)$ \\
\hline
\end{tabular}

trial between ages 3 and 23, hence allowing for a thorough analysis of the trend in heritability and the corresponding ageage correlations over an extended period of time. The heritability increased from 0.10 at age 3 to a maximum of 0.36 at age 17 , dropping somewhat afterwards, to $h^{2}=0.22$. In the second-generation trials, measured between ages 1 and 4 , heritability for diameter and height also improved with age, from around $h^{2}=0.14-0.21$ at 1 year to $h^{2}=0.20-0.32$ at 4 years. HTPC had a much higher heritability than growth, ranging between 0.42 and 0.69 . Wood density, based on cores at age 11 , had a heritability of 0.28 .

The correlation between height, diameter, and volume was consistently strong at all ages $\left(r_{\mathrm{G}}\right.$ ranged between 0.66 and 0.98; data not shown), as well as the correlation between traits measured at different ages (Tables 6 and 7), except for measurements taken at ages younger than 2 years.

The genetic correlation between diameter and density at age 11, estimated only at the La Florida site, was $0.07 \pm 0.19$ (Table 7). The correlations between height or diameter and
HTPC at age 3, assessed in the second-generation trials, were in general positive but low to moderate in magnitude (Table 8).

The across-site genetic correlations for HTPC were always high (around 0.9; Table 9), as were the correlations between BLUP estimates of race effects (at around 0.7; results not shown). Finally, the pairwise, across-site genetic correlations for diameter growth were consistently high among the three second-generation trials (from 0.75 to 0.87 ), but not between either of them and the first-generation trial at the La Florida site (correlations between -0.03 and 0.34 ; Table 9).

\section{Discussion}

The relative performance of E. globulus races and provenances has been investigated previously (see Eldridge et al. 1997; Potts et al. 2004 for a review), but these studies have focused on mid-latitude regions, such as the specie's
Table 4 Race effects in the three second-generation trials (Firavitoba-Fv, Santa Rosa-Sr, and Tuta-Tu), for height (in meters), dbh (in centimeters), estimated volume (in cubic decimeter per tree) at age 4, and HTPC at age
3. A Wald $F$ test and the expected probability of a significance difference are also presented

\begin{tabular}{|c|c|c|c|c|c|c|c|c|c|c|c|c|}
\hline Race & $\begin{array}{l}\text { Fv } \\
\text { Height }\end{array}$ & $\mathrm{Sr}$ & $\mathrm{Tu}$ & $\begin{array}{l}\mathrm{Fv} \\
\mathrm{dbh}\end{array}$ & $\mathrm{Sr}$ & $\mathrm{Tu}$ & $\begin{array}{l}\text { Fv } \\
\text { Volume }\end{array}$ & $\mathrm{Sr}$ & $\mathrm{Tu}$ & $\begin{array}{l}\text { Fv } \\
\text { HTPC }\end{array}$ & $\mathrm{Sr}$ & $\mathrm{Tu}$ \\
\hline Colombia LR & 10.6 & 15.6 & 8.8 & 8.4 & 12.5 & 7.4 & 23.98 & 78.79 & 15.25 & 4.8 & 5.0 & 4.3 \\
\hline $\begin{array}{l}\text { Southern } \\
\text { Tasmania }\end{array}$ & 10.9 & 15.9 & 8.9 & 8.4 & 12.7 & 7.3 & 24.11 & 82.30 & 15.38 & 4.8 & 5.2 & 4.3 \\
\hline NE Tasmania & 10.9 & 15.8 & 8.7 & 8.7 & 13.0 & 7.3 & 25.68 & 85.42 & 15.38 & 4.9 & 5.3 & 4.4 \\
\hline SE Tasmania & 10.9 & 16.0 & 8.9 & 8.5 & 12.6 & 7.3 & 24.39 & 80.74 & 15.27 & 4.1 & 4.6 & 4.0 \\
\hline $\begin{array}{l}\text { Western } \\
\text { Tasmania }\end{array}$ & 10.9 & 15.7 & 9.1 & 8.6 & 13.0 & 7.7 & 26.20 & 87.98 & 17.79 & 3.8 & 4.2 & 3.6 \\
\hline Recherche Bay & 10.9 & 16.1 & 9.0 & 8.7 & 12.4 & 7.6 & 26.02 & 76.80 & 17.59 & 4.3 & 4.6 & 4.1 \\
\hline King Island & 11.0 & 15.8 & 8.6 & 8.4 & 12.9 & 6.9 & 24.83 & 85.37 & 14.05 & 4.1 & 3.9 & 3.7 \\
\hline Furneaux & 10.4 & 15.9 & 9.0 & 8.3 & 12.9 & 7.6 & 24.85 & 86.63 & 17.15 & 3.2 & 4.0 & 3.8 \\
\hline$F$-inc (prob) & $\begin{array}{l}1.22 \\
(0.29)\end{array}$ & $\begin{array}{l}0.77 \\
(0.61)\end{array}$ & $\begin{array}{l}0.79 \\
(0.60)\end{array}$ & $\begin{array}{l}0.87 \\
(0.53)\end{array}$ & $\begin{array}{l}1.08 \\
(0.37)\end{array}$ & $\begin{array}{l}1.24 \\
(0.28)\end{array}$ & $\begin{array}{l}0.87 \\
(0.53)\end{array}$ & $\begin{array}{l}1.4 \\
(0.20)\end{array}$ & $\begin{array}{l}1.46 \\
(0.18)\end{array}$ & $\begin{array}{l}4.76 \\
\quad(<0.01)\end{array}$ & $\begin{array}{l}4.71 \\
\quad(<0.01)\end{array}$ & $\begin{array}{l}3.75 \\
\quad(<0.01)\end{array}$ \\
\hline
\end{tabular}


Table 5 Heritability for height; dbh; height to phase change and density at ages $1-23$ at the La Florida (first-generation) and Firavitova, Santa Rosa, and Tuta (second-generation) progeny trials; and associated standard errors (in parenthesis)

\begin{tabular}{ccccc}
\hline Trait/age (years) & La Florida & Firavitoba & Santa Rosa & Tuta \\
\hline Height & & & & \\
1 & & $0.16(0.05)$ & $0.21(0.05)$ & $0.14(0.05)$ \\
2 & & $0.19(0.05)$ & $0.32(0.06)$ & $0.22(0.05)$ \\
3 & & $0.16(0.05)$ & $0.33(0.06)$ & $0.22(0.05)$ \\
4 & & $0.21(0.05)$ & $0.32(0.06)$ & $0.20(0.05)$ \\
dbh & & & & \\
3 & $0.10(0.06)$ & $0.21(0.05)$ & $0.29(0.06)$ & $0.18(0.05)$ \\
4 & $0.27(0.06)$ & $0.40(0.07)$ & $0.24(0.06)$ \\
11 & $0.29(0.07)$ & & & \\
17 & $0.36(0.08)$ & & & \\
23 & $0.22(0.07)$ & & & \\
Height to phase change & & & \\
3 & & $0.69(0.09)$ & $0.42(0.07)$ & $0.46(0.08)$ \\
Density & & & & \\
11 & $0.28(0.07)$ & & & \\
\hline
\end{tabular}

native ranges in Tasmania and Southern Victoria, with oceanic temperate climate and near uniform precipitation around the year (climate type $\mathrm{Cfb}$ ), or in dry summer subtropical or Mediterranean conditions (of climate type Cs) as in Portugal, Spain, Chile, and western Australia. The conditions reported here for the interior highlands of Colombia are different and unique, although well within the range of temperatures and

Table 6 Age-age correlations between ages 1-4 for height (above diagonal) and dbh (below diagonal) for the second-generation trials of Firavitoba, Santa Rosa, and Tuta and associated standard errors (in parenthesis)

\begin{tabular}{clll}
\hline & 2 & 3 & 4 \\
\hline $\begin{array}{ccl}\text { Firavitoba } \\
1\end{array}$ & $0.69(0.12)$ & $0.32(0.19)$ & $0.36(0.18)$ \\
2 & & $0.78(0.09)$ & $0.48(0.15)$ \\
3 & $0.99(0.07)$ & & $0.89(0.04)$ \\
4 & $0.91(0.08)$ & $0.97(0.01)$ & \\
Santa Rosa & & & $0.58(0.12)$ \\
1 & $0.88(0.06)$ & $0.71(0.10)$ & $0.84(0.06)$ \\
2 & & $0.93(0.03)$ & $0.96(0.02)$ \\
3 & $1.00(0.04)$ & & \\
4 & $0.93(0.05)$ & $0.97(0.01)$ & $0.49(0.16)$ \\
Tuta & & & $0.67(0.10)$ \\
1 & $0.82(0.07)$ & $0.62(0.13)$ & $0.92(0.03)$ \\
2 & & $0.83(0.06)$ & \\
3 & $0.97(0.02)$ & & \\
\hline
\end{tabular}

Table 7 Age-age genetic correlations between dbh $(D)$ at ages 3, 11, 17, and 23 years and between diameter and wood density (DEN) at age 11 at the La Florida trial and associated standard errors (in parenthesis)

\begin{tabular}{lllll}
\hline & DEN11 & D11 & D17 & D23 \\
\hline D3 & & $0.64(0.21)$ & $0.60(0.22)$ & $0.53(0.28)$ \\
D11 & $0.07(0.19)$ & & $0.99(0.02)$ & $1.00(0.06)$ \\
D17 & & & & $1.00(0.07)$ \\
\hline
\end{tabular}

rainfall suitable for the species. The climate can be classified as temperate highland tropical (of type $\mathrm{Cwc}$ ), with two distinct wetter periods, cool conditions throughout the year, and lack of any serious drought period. Also, soils are of volcanic origin, deep, well drained, and moderately fertile, in contrast with the generally poorer soils where E. globulus is usually tested.

The results indicate that race effects are not important for growth. Differences were only statistically significant in the older trial, which was based on native stand seed. Here, King Island was the best race until age 11, although differences disappeared by age 23. King Island has been found as one of the fastest growing sources in other studies (e.g., Volker and Orme 1988), albeit also more susceptible to drought (Soria and Borralho 1997; Dutkowski 1995; Dutkowski and Potts 2012). In some of these studies, some races have been proven to be often superior in growth to King Island, namely, Otways and Strezlezcki Range (e.g., Jordan et al. 1994). Unfortunately, these races are not represented in the present collection. The Colombian landrace, of unknown origin, was intermediate in growth. Given the relatively large intra-race genetic variance and the modest race differences found, there would be no reason to favor selection within any specific race as outstanding individuals are likely to be found across all of them, including the Colombian landrace. However, race differences have been more marked for the other traits. Density was significantly lower in King Island and Recherche Bay, whereas the Colombian landrace had the highest density of the lot. King Island is well known for its lower wood density (e.g., Dutkowski and Potts 1999). Given the importance of wood density for pulpwood production (e.g., Borralho et al. 1993; Greaves et al. 1997), the results

Table 8 Genetic correlations between dbh $(D)$, height $(H)$, estimated volume $(V)$, and HTPC at age 3 years in Firavitoba, Santa Rosa, and Tuta sites and associated standard errors (in parenthesis)

\begin{tabular}{llll}
\hline & H versus HTPC & D versus HTPC & V versus HTPC \\
\hline Firavitoba & $0.14(0.14)$ & $0.30(0.13)$ & $0.26(0.13)$ \\
Santa Rosa & $0.07(0.16)$ & $0.05(0.15)$ & $0.00(0.15)$ \\
Tuta & $0.07(0.16)$ & $0.48(0.11)$ & $0.49(0.11)$ \\
\hline
\end{tabular}


Table 9 Between-trial genetic correlations for diameter at age 3 (diagonal and above diagonal) and for height to phase change at age 3 (below diagonal) and associated standard errors (in parenthesis)

\begin{tabular}{llll}
\hline & Santa Rosa & Tuta & La Florida \\
\hline Firavitoba & $0.77(0.13)$ & $0.87(0.10)$ & $0.07(0.28)$ \\
Santa Rosa & $0.95(0.05)$ & $0.84(0.10)$ & $-0.33(0.28)$ \\
Tuta & $0.96(0.05)$ & $0.88(0.07)$ & $0.01(0.26)$ \\
\hline
\end{tabular}

emphasize the importance of the Colombian landrace material as a useful genetic resource for further selection, and certainly discourage the use of King Island and Recherche Bay, despite their good growth. Race differences were also highly significant for HTPC. King Island, Western Tasmania, and Flinders Island changed leaf type at a higher tree height (and at a later age) compared with the Colombian landrace and Eastern Tasmanian races. The mean race values for HTPC were very similar with those reported by Jordan et al. (2000), Dutkowski and Potts (1999), and Potts et al. (2004). Although no detailed analysis of the architecture of the crown was conducted, the results suggest that taller trees would result from both longer internodes (Jordan et al. 2000), and more of them, hence the less than proportional HTPC relative to total height. Based on its relative performance for growth, but especially considering the wood density and HTPC estimates, the results suggest that the Colombian landrace may be genetically distinct from both the Tasmanian and Bass Strait races present. This may point to a Victorian origin, something which can only be confirmed with the use of molecular markers, as done elsewhere (Freeman et al. 2007).

Heritability estimates for growth are within the upper range reported for the species (see Potts et al. 2004; Stackpole et al. 2010 for a review on this topic) and provide ample opportunities for effective selection for growth. HTPC had a higher heritability, which is consistent with other estimates (e.g., Dutkowski and Potts 1999; Jordan et al. 1999, 2000; Hamilton et al. 2013). Finally, the heritability estimate for density was 0.28 , which is lower than usually reported for eucalypts (e.g., Borralho et al. 1992a; Raymond and Apiolaza 2004). This may be due to the poor accuracy of the volume displacement methods (to measure green volume) when wood samples are small, as with tree cores used here.

The two series of trials have a somewhat different genetic structure. In the first-generation trial, the Australian seed was collected in native stands; hence, the open-pollinated families are expected to express some within-stand neighborhood inbreeding (viz., Hardner et al. 1996). In the secondgeneration series of trials, seed was collected ex situ and is expected to have been pollinated by a mix of unrelated parents at the La Florida site. The pollination would include several races, and this would result in a breakdown of the ancestral relatedness present in the original collection. Comparing the genetic parameter estimates from the two series of trials at the same age (i.e., 3 years), the La Florida trial had a significantly lower heritability $\left(h^{2}=0.10\right)$ than the other three trials $(0.18$ 0.29 ). This is surprising, firstly because one would expect that the intra-family inbreeding present in the native stand material would exacerbate family differences and heritabilities (viz., Borralho and Potts 1996; Potts et al. 2004; Costa-e-Silva et al. 2010a, b). Secondly, the La Florida site was selectively thinned, with the worse trees within a plot being removed. This is expected to reduce the within-family variance, and therefore biasing upwardly the heritability (viz., Matheson and Raymond 1984). Nevertheless, by age 11, the heritability at La Florida recovered and was similar to the other three trials.

A consistent result across trials was the increase in heritability over time. This is expected since annual increments were strongly correlated. Henceforth, late assessments can be considered as repeated measurements of early ones, causing the residual deviations of each annual increment to drop and the accuracy to improve with time (viz., Wei and Borralho 1996). Only at very early ages (2 years or less) was height a poor indicator of later volume. This suggests that selection should not be done earlier than age 3, a conclusion which agrees with previous studies by Borralho et al. (1992b) and Greaves et al. (2003). After age 3, age-age correlations remained high even when age intervals were as long as 20 years $\left(r_{\mathrm{G}}=0.53\right)$. After age 11 , age-age correlations were consistently close to 1 .

Growth and density were genetically independent, with a correlation very close to 0 , a result which is consistent with other studies in Eucalyptus (e.g., Muneri and Raymond 2000). Since growth and density are key traits in breeding for pulpwood production, the lack of association between them implies that the two should be included in the selection criteria; otherwise, overall gains would be suboptimum (Borralho et al. 1993; Greaves et al. 1997).

Genetic correlation between growth and HTPC was positive, but low (around 0.40). Interestingly, the result suggests that correlation was stronger with diameter than with height, a result which deserves some further investigation since it was also found in Jordan et al. (2000) and Lopez et al. (2002). This result suggests that breeding programs which select primarily for early growth are likely to lead to plantations with later leaf type changes. This may be a concern in areas prone to the attack of Teratosphaera nubilosa, a serious disease which affects only the juvenile foliage (Hunter et al. 2009; Milgate et al. 2005). On the other hand, delaying the change of foliage to adult type may be of some advantage since it may delay the impact of defoliation by Gonipterus and other adult leaf eater insects (viz., de Little et al. 2008). Since neither of these constitute a current problem in Colombia, it is difficult to attribute a particular selective advantage to HTPC. 
The magnitude of genotype-by-environment interactions at the race or family level was of little importance for growth and HTPC between the three second-generation trials. Strong environmental stability for growth and HTPC has been reported for E. globulus even when tested across a much wider range of conditions and countries (Costa-e-Silva and Dutkowski 2006). However, the genetic correlation for growth between the La Florida site and any of the other three sites was low and, in one occasion, slightly negative, although estimates were associated with large standard errors. Such poor correspondence between the family merits at La Florida and the other three sites is unlikely to be due to genotypeenvironment interactions since sites have very similar characteristics. The lower degree of relatedness between families present at La Florida and the other three trials (average relatedness coefficient of 1/8) may explain the poor and unreliable nature of the correlation found. However, another possible explanation for the poor correspondence may be the impact of inter-race outcrossing which is likely to be present in the second-generation group of families. Given the similar flowering season among most Tasmanian and Bass Strait races (viz., Jones et al. 2011), one would expect that there has been a fair amount of pollen mix in the open-pollinated families. One would also expect the amount of selfing in second-generation open-pollinated families to be lower than the one found in native stand collections, although this may be debatable and high selfing has been reported in seed orchard seed too (e.g., Patterson et al. 2004). However, Hodge et al. (1996) and Volker (2002) also found modest correlations between parental breeding values based on "closed" versus "distant" crosses. In particular, the correlation between parental breeding values from native open-pollinated versus "distant" controlled-pollinated crosses was particularly poor.

\section{Conclusions}

The results found here are the first ones reported for $E$. globulus ssp. globulus growing in the unique environmental conditions found in the high Andean plateau of Central Colombia. For growth traits, they confirmed a low racial differentiation, moderate levels of genetic control, and stable family (genetic) performance across sites. On the other hand, racial differences were marked for wood density, with the Colombian landrace having the highest density. Although the merit of the Colombian landrace could not be established against other preeminent E. globulus races, such as Otways and Strezlecki Ranges, absent in the current collection, the combined analysis of growth and wood density suggests that the Colombian landrace material should be an important genetic resource for the future. The very poor genetic correlation found between ex-native and ex situ families suggests that progeny trials from native stand collections, although important from the point of view of genetic conservation, may be too unreliable to rank families and races. Forward selections should therefore focus on information coming as much as possible from the expectedly more outcrossed advanced-generation material.

Race effects and heritability were strong for height to phase change, and the results were highly stable across sites. Although there was a clear positive environmental relationship with site productivity, from a genetic viewpoint, growth and height to phase change appear to be only slightly positively correlated. The Colombian landrace tends to retain juvenile leaves longer and grow less compared with races from Furneaux Group or Western Tasmania, although as mentioned previously, there is considerable scope for improvement in both characteristic within races. Hence, from the strict point of view of stand productivity, there seems to be little advantage in late leaf change. However, the ecological and economic relevance of timing of phase change may change in the future since leaf type is related with susceptibility to several pests of economic importance.

Acknowledgments The establishment and maintenance of the secondgeneration trials has been a joint effort between Smurfit Kappa Cartón de Colombia S. A. (SKCC), Reforestadora El Guásimo, Reforestadora del Caribe S. A. S, Corporación Nacional de Investigación y Fomento Forestal-CONIF, Universidad Distrital "Francisco José de Caldas". The project has been partially financed by the Ministério de Agricultura y Desarrollo Rural (contract no. 348/2006, agreement no. 002/2006 alliance IICA-MADR) and Colciencias. We would also like to thank Hugo España (SKCC) and colleagues and to all the forestry students who, under the leadership of Professor Jairo Silva, have been responsible for maintaining and measuring the La Florida site over the years.

\section{References}

Borralho NMG, Cotterill PP, Kanowski PJ (1992a) Genetic parameters and gains expected from selection for dry weight in Eucalyptus globulus ssp. globulus in Portugal. Forest Sci 38:80-94

Borralho NMG, Cotterill PP, Kanowski PJ (1993) Breeding objectives for pulp production of Eucalyptus globulus under different industrial cost structures. Can J Forest Res 23:648-656

Borralho NMG, Kanowski PJ, Cotterill PP (1992b) Genetic control of growth of Eucalyptus globulus in Portugal. II. Efficiencies of early selection. Silvae Genet 41:70-77

Borralho NMG, Potts BM (1996) Accounting for native stand characteristics in genetic evaluations of open-pollinated progeny from a Eucalyptus globulus base population. New Forest 11:53-64

Brennan EB, Weinbaum SA (2001) Performance of adult psyllids in nochoice experiments on juvenile and adult leaves of Eucalyptus globulus. Entomol Exp Appl 100:179-185

Costa-e-Silva J, Potts BM, Dutkowski G (2006) Genotype by environment interaction for growth of Eucalyptus globulus in Australia. Tree Genet Genomes 2:61-75

Costa-e-Silva J, Potts BM, Hardner CM (2010a) Genetic variation and parental performance under inbreeding for growth in Eucalyptus globulus. Ann Forest Sci 67:606. doi:10.1051/forest/2010019 
Costa-e-Silva J, Hardner CM, Tyliard P, Potts BM (2010b) Effects of inbreeding on population mean performance and observational variances in Eucalyptus globulus. Ann Forest Sci 67:605. doi:10. 1051/forest $/ 2010018$

de Little DW, Foster SD, Hingston TL (2008) Temporal occurrence pattern of insect pests and fungal pathogens in young Tasmanian plantations of Eucalyptus globulus Labill. and E. nitens Maiden. Pap Proc R Soc Tasmania 142:61-69

Da Y, Grossman M (1991) Multitrait animal model with genetic groups. J Dairy Sci 74:3183-3195

Dutkowski GW (1995) Genetic variation in drought susceptibility of Eucalyptus globulus ssp. globulus in plantations in Western Australia. In: Potts BM, Borralho NMG, Reid JB, Cromer RN, Tibbits WN, Raymond CA (eds) Eucalyptus plantations: improving fibre yield and quality. CRC-IUFRO, Hobart, pp 199-203

Dutkowski GW, Potts BM (1999) Geographic patterns of genetic variation in Eucalyptus globulus ssp. globulus and a revised racial classification. Aust J Bot 47:237-262

Dutkowski GW, Potts BM (2012) Genetic variation in the susceptibility of Eucalyptus globulus to drought damage. Tree Genet Genomes 8: 757-773

Eldridge K, Davidson J, Harwood C, van Wyk G (1997) Eucalypt domestication and breeding. Oxford Science Publications, Oxford

Freeman J, Marques CMP, Carocha V, Borralho NMG, Potts BM, Vaillancourt RE (2007) Origins and diversity of the Portuguese landrace of Eucalyptus globulus. Ann Forest Sci 64:639-647

Gilabert H, Paci C (2010) An assessment of volume-ratio functions for Eucalyptus globulus and E. nitens in Chile. Cienc Investig Agrar 37:5-15

Gilmour AR, Cullis BR, Welham SJ, Thompson R (1998) ASREML users' manual. New South Wales Agriculture, Orange

Greaves BL, Borralho NMG, Raymond CA (1997) Breeding objective for plantation eucalypts grown for production of kraft pulp. Forest Sci 43:465-472

Greaves BL, Borralho NMG, Raymond CA (2003) Early selection in eucalypt breeding in Australia - optimum selection age to minimise the total cost of kraft pulp production. New Forest 25:201-210

Hamilton MG, Williams DR, Tilyard PA, Pinkard EA, Wardlaw TJ, Glen M, Vaillancourt RE, Potts BM (2013) A latitudinal cline in disease resistance of a host tree. Heredity 110:372-379

Hardner CM, Vaillancourt R, Potts BM (1996) Stand density influences outcrossing rate and growth of open-pollinated families of Eucalyptus globulus. Silvae Genet 45:226-228

Hodge GR, Volker PW, Potts BM, Owen JV (1996) A comparison of genetic information from open-pollinated and control-pollinated progeny tests in two eucalypt species. Theor Appl Genet 92:5363

Hunter GC, Crous PW, Carnegie AJ, Wingfield MJ (2009) Teratorphaeria nubilosa, a serious leaf disease pathogen of Eucalyptus ssp. in native and introduced areas. Mol Plant Pathol 10:1-14

Jones RC, Vaillancourt RE, Gore PL, Potts BM (2011) Genetic control of flowering time in Eucalyptus globulus ssp. globulus. Tree Genetic Genomes 7:1209-1218

Jordan G, Potts BM, Wiltshire RJ (1999) Strong, independent, quantitative genetic control of the timing of vegetative phase change and first flowering in Eucalyptus globulus ssp. globulus (Tasmanian Blue Gum). Heredity 83:179-187

Jordan G, Borralho NMG, Tyliard P, Potts BM (1994) Identification of races in Eucalyptus globulus ssp. globulus based on growth traits in Tasmania and geographic distribution. Silvae Genet 43:292-298

Jordan G, Potts BM, Chalmers P, Wiltshire RJ (2000) Quantitative genetic evidence that the timing of vegetative phase change in Eucalyptus globulus ssp. globulus is an adaptive trait. Aust J Bot 48:561-567
Kottek M, Grieser J, Beck C, Rudolph B, Rubel F (2006) World map of the Köppen-Geiger climate classification updated. Meteorol Z 15: 259-263

Lopez GA, Potts BM, Dutkowski G, Apiolaza L, Gelid P (2002) Genetic variation and inter-trait correlations in Eucalyptus globulus base population trials in Argentina. Forest Genetic 9:214-231

Lynch M, Walsh B (1998) Genetics and analysis of quantitative traits. Sinauer Associates, Sunderland

Matheson AC, Raymond CA (1984) Effects of thinning in progeny tests on estimates of genetic parameters in Pinus radiata. Silvae Genet 33:125-130

McCullagh P, Nelder JA (1989) Generalized linear models, vol. 37. Monographs on statistics applied probability. Chapman \& Hall, London

Milgate AW, Potts BM, Joyce K, Mohammed C, Vaillancourt RE (2005) Genetic variation in Eucalyptus globulus for susceptibility to Micosphaerella nubilosa and its association with tree growth. Australas Plant Pathol 34:11-18

Muneri A, Raymond CA (2000) Genetic parameters and genotype-byenvironment interactions for basic density, pilodyn penetration and stem diameter in Eucalyptus globulus. Forest Genet 7:317-328

Orme RK (1978) Eucalyptus globulus provenances. Documents FAO. Third World Consultation on Forest Tree Breeding, vol. 1, Canberra, pp 207-221

Patterson B, Vaillacourt RE, Pilbeam DJ, Potts BM (2004) Factors affecting variation in outcrossing rate in Eucalyptus globulus. Aust J Bot 52:773-780

Potts BM, Vaillancourt RE, Jordan G, Dutkowski G, Silva JC, McKinnon G, Steane D, Volker P, Lopez G, Apiolaza L, Li Y, Marques C, Borralho NMG (2004) Exploration of the Eucalyptus globulus gene pool. In: Borralho NMG, Pereira JS, Marques C, Coutinho J, Madeira M, Tomé M (eds) Proceeding of IUFRO Conference "Eucalyptus in a changing world". RAIZ, Aveiro, pp 46-61

Raymond CA, Apiolaza LA (2004) Incorporating wood quality and deployment traits in Eucalyptus globulus and Eucalyptus nitens. In: Plantation forest biotechnology for the 21 st century. Research Signpost, Kerala, India, pp 87-99

Salas M, Salazar M (2007) Evaluación Fenotípica del huerto semillero de Eucalyptus globulus La Florida y determinación del protocolo de injertación orientado a la propagación de individuos sobresalientes. Universidad Distrital Francisco José de Caldas, Bogotá

Soria F, Borralho NMG (1997) The genetics of resistance to Phoracantha semipunctata attack in Eucalyptus globulus in Spain. Silvae Genet 46:365-369

Squillace AE (1974) Average genetic correlations among offspring from open-pollinated forest trees. Silvae Genet 23:149-156

Stackpole DJ, Vaillancourt RE, Aguigar M, Potts BM (2010) Age trends in genetic parameters for growth and wood density in Eucalyptus globulus. Tree Genetic Genomes 6:179-193

Steinbauer MJ (2002) Oviposition preference and neonate performance of Mnesampela provata in relation to heterophylly in Eucalyptus dunnii and E. globulus. Agr Forest Enthomol 4:245-253

Venegas L (1989) Instalación y manejo de un huerto semillero de Eucalyptus globulus Labill en Cololombia. Investigación Forestal, vol. 25. INDERENA, Bogotá

Volker PW (2002) Quantitative genetics of Eucalyptus globulus, E. nitens and their F1 hybrid. University of Tasmania, Hobart

Volker PW, Orme K (1988) Provenance trials of Eucalyptus globulus and related species in Tasmania. Austral For 51:257-265

Wei X, Borralho NMG (1996) A simple model to describe age trends in heritability in short rotation tree species. In: Dieters MJ, Matheson AC, Nikles DG, Harwood CE, Walker SM (eds) IUFRO Conference on Tree Improvement for Sustainable Tropical Forestry. QFRI, Caloundra, Queensland, pp 178-181

Westell RA, Quaas RL, van Vleck LD (1988) Genetic groups in an animal model. J Dairy Sci 71:1310-1318 